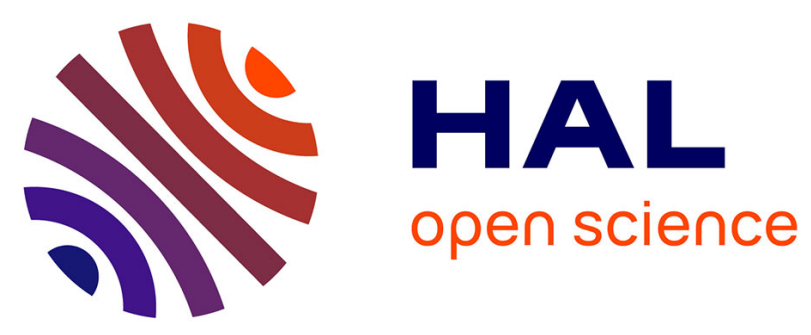

\title{
Chapter 11 - Conceptual Approaches, Methods and Models Used to Assess Abstraction Limits for Unconfined Aquifers in France
}

Luc Arnaud

\section{- To cite this version:}

Luc Arnaud. Chapter 11 - Conceptual Approaches, Methods and Models Used to Assess Abstraction Limits for Unconfined Aquifers in France. Sustainable Groundwater Management, Global Issues in Water Policy, pp.239-268, 2020, 10.1007/978-3-030-32766-8_11 . hal-02613469

\section{HAL Id: hal-02613469 \\ https: / hal-brgm.archives-ouvertes.fr/hal-02613469}

Submitted on 20 May 2020

HAL is a multi-disciplinary open access archive for the deposit and dissemination of scientific research documents, whether they are published or not. The documents may come from teaching and research institutions in France or abroad, or from public or private research centers.
L'archive ouverte pluridisciplinaire HAL, est destinée au dépôt et à la diffusion de documents scientifiques de niveau recherche, publiés ou non, émanant des établissements d'enseignement et de recherche français ou étrangers, des laboratoires publics ou privés. 


\title{
Chapter 11. Conceptual approaches, methods and models used to assess abstraction limits for unconfined aquifers in France
}

\author{
Luc Arnaud \\ BRGM (French Geological Survey), Orléans, France \\ Corresponding author: $\underline{1 . a r n a u d @ b r g m . f r}$
}

\begin{abstract}
This chapter presents a review of methods an tools used in France to assess groundwater abstraction limits in unconfined aquifers. The experience gained from over 30 studies shows that the estimation of Maximum Permissible Volume (MPV) is complicated by numerous uncertainties. The first prerequisite is a good knowledge of the dynamics of the hydrosystems and abstraction volumes, but unfortunately this is rarely achieved. Moreover, both the calculation methods and modelling tools that aim to conceptualize these complex systems have limitations due to the simplifying assumptions required for their application. Technical recommendations are proposed for a proper assessment of such uncertainties. In many cases, the calculated maximum permissible volumes were much lower than the previously authorized volumes. Therefore, many of the results were contested by affected users. Such disputes concerned not only the economic consequences of reduced abstraction, but also the scientific basis of the studies in view of the known uncertainties and limitations. The last section of this chapter discusses this phase of negotiations, specifically based on examples from the Adour-Garonne water basin in southwest France.
\end{abstract}

Keywords : Abstraction limits, Calculation methods, Hydrogeological models, Uncertainties, Unconfined aquifers.

\section{Introduction}

The French law on water and aquatic environments of 30 December 2006 requires the implementation of volumetric water-abstraction management in all river basins that are considered as being water deficient. Such volumetric management is mainly based on the definition of an abstraction limit, specified in volume, that the 
State must respect when delivering the yearly abstraction authorizations (see Chapter 3).

In its circular of 30 June 2008, the French Ministry for Ecology defines a maximum permissible volume (MPV) as "the water volume that the environment can supply under satisfying ecological conditions". In order to consider climatic variability, the MPV is statistically calculated so as to guarantee that, for 8 out of 10 years, such abstraction does not jeopardize the good quantitative, qualitative and ecological status of the water resources and their associated aquatic environments. Contrary to Australia, this French approach is purely environmental, and does not consider actual water use and its economic importance.

An MPV calculation considers where the abstraction is located. Rather than an absolute value, it is a value associated to the spatial distribution of wells and boreholes, and the distribution of water abstraction between them. A significant modification of the spatial distribution thus will result in a modification of the MPV.

An MPV calculation thus requires in-depth hydrogeological understanding. In this chapter, we present lessons learnt from recent French studies for determining the MPVs in unconfined aquifers, where the possible hydraulic connection between groundwater and surface water renders such evaluation particularly delicate. Our analysis is based on a review of over thirty studies, carried out by various organizations between 2008 and 2015 (Arnaud, 2016).

The first section of the chapter reviews the methods and tools used in the studies, and describes the criteria that determined which method was chosen. The second section describes the main difficulties and limits of the various methods employed, as well as the uncertainty associated with produced results. Technical recommendations are proposed for a proper assessment of such uncertainties. The third section discusses the phase of negotiations between stakeholders, experts and government agencies that generally follows after the technical studies, which eventually leads to a regulatory definition of the MPVs. This last section is specifically based on examples from the Adour-Garonne water basin in southwest France, a region where the assessment of MPVs has generated significant conflict and disputes.

\section{Review of methods and tools for MPV calcula- tion}

Following the publication of the 2006 Water Law, the Ministry for Ecology in charge of implementing the new legal framework did not impose a specific method for calculating maximum permissible volumes. The reason was that a single methodology, regardless of its relevance, cannot cover the great variety of hydrogeological settings found in France. This decision has allowed experts and managers responsible for determining the MPVs to use a diverse range of methods that are presented hereafter. 


\subsection{General approach for assessing MPV in the context of an un- confined aquifer}

Even though tools and methods can vary greatly from one study to the next, MPV studies are generally organized into nine main stages. This framework was first adopted by the Rhône-Méditerranée-Corse Water Agency in order to integrate the various studies carried out in its region.

1. A steering committee is appointed before each study, with the objective of including all stakeholders affected by the study, involving them in the technical decisions during the study and facilitating the adoption of the results. The committee generally consists of representatives of national and local government services, the Water Agency, water managers and other stakeholders.

2. The second stage consists of creating a conceptual model describing the main characteristics of the aquifer and its flow systems. In the case of unconfined aquifers, particular attention should be paid to defining the interaction between groundwater and surface water, and to the evaluation of the recharge. This is because the final selection of the method for determining maximum permissible volumes is in large part governed by the hydrogeological setting.

3. Stage 3 consists of conducting a complete inventory of abstractions and discharges. Given that the data collected by government agencies generally are incomplete, further work will be often be needed. For example, water abstraction declared by irrigators can be compared to the theoretical irrigation-water requirements corresponding to the irrigated areas, which can be measured using satellite imagery.

4. The steering committee then defines the environmental objectives that must be respected. They will differ according to their context, such as: maintaining minimal flow in a stream connected to an aquifer; limiting saline intrusion into coastal aquifers; avoiding flow reversal between different aquifers near a wetland; respecting the long-term equilibrated groundwater budget, etc. In some cases, the environmental objectives can be defined beforehand as part of a Water Management Plan established at the local or river catchment level (SAGE and SDAGE respectively, see chapter 4).

5. The next stage consists in selecting the scientific methods and tools which will be used for calculating the MPV. At a minimum, retrospective analysis of climatic, hydrological and hydrogeological observations must be carried out. Depending on the quality of the available data, the use of groundwater flow models may be possible.

6. Stage 6 consists in defining appropriate management areas on the basis of hydrological and hydrogeological criteria. The MPVs will then be determined at the scale of these management areas. 
7. For each zone, indicators are defined for measuring how the environmental objectives are going to be met. Generally, these are groundwater levels in specific monitoring wells, associated with river flows measured at specific gauging stations during low water periods. Other indicators can be added, such as the frequency and duration of periods during which the riverbed becomes dry, the salinity of water, etc.

8. The MPVs can then be estimated for each management area, ideally with monthly time steps and being appropriate for dry seasons.

9. Finally, the MPV study should highlight the limitations of the analysis and propose recommendations for future improvement (collecting further data, etc.). An MPV estimate should not remain fixed in time and regular updates are required by law. The aim is to progressively incorporate new hydro-climatic datasets, modelling updates, a better understanding of local conditions, etc.

\subsection{Calculating maximum permissible volume without using a groundwater model}

Once the environmental objectives have been defined, three methods can be used for evaluating the MPVs.

The simplest approach consists of a retrospective analysis of climatic, hydrologic and hydrogeologic datasets. By examining historical trends, the maximum volume that has been abstracted in the past without jeopardizing environmental objectives can be identified over a range of climatic conditions. Unfortunately, this highly pragmatic approach is rarely used, even though it has the advantage of very easy implementation and enables a comparison of the estimated MPVs with the observed responses in the field. It seems particularly suitable in the case of systems that are or were exposed to known overexploitation.

A good example is the case of the alluvial Gapeau aquifer in the Var department, where chronic over-use led to saltwater intrusion from the Mediterranean Sea in the past. A cross-analysis of available datasets was carried out by the consulting firm Grontmij (2014). This allowed identification of those volumes abstracted in the past that not only maintained groundwater levels above sea level, but also prevented saline intrusion, under different precipitation conditions ranging from below to above average rainfall.

Based on the quantity of available data and their existing correlations, more indepth data processing may be possible. The work by the Calligée consulting firm in 2008 on the aquifers of South Vendée (western France) is an interesting example. Their study showed the existence of a linear relation between static water levels and abstracted volumes during summer. This allowed deduction of a mathematical equation for estimating the permissible volume that could be abstracted from the aquifer at the start of the growing season. This equation then was adjusted to be statistically valid for four out of five years. Use of this method requires detailed 
knowledge of abstractions (bi-monthly frequency in this instance), and is only suitable for low-storage aquifers with a seasonal response to recharge and discharge.

In short, even though such analyses may not always result in determining the MPVs that can be abstracted, they should be seen as an important preliminary step for any modelling exercise. They not only allow a first evaluation of the available data, but also provide an understanding of aquifer behaviour under pumping, and an indication of data gaps and recommendations for further investigations.

\subsection{Calculating maximum permissible volume using global models}

Figure 11. 1 shows the two main types of global models used in hydrogeology (Richard, 2010; Aditya et al., 2015). The first type is based on a schematic and very simplified representation of hydrological systems and processes. It generally consists in a series of reservoirs representing aquifers and river stretches connected by simple hydrological functions. The second, "black box", type is based on establishing a mathematical relationship between a output variable describing the condition of the hydrosystem being studied (e.g. the water level in the aquifer, or the flowrate in a river depending on the aquifer, in Fig. 11.1), and one or more input variables determining this condition (rainfall, evapo-transpiration, abstraction). This mathematical relationship is called a transfer function.

As global models are not spatialized and do not describe the physical environment, they require few data inputs (precipitation, ETP, static water level, flow-rate) and have the advantage of rapid implementation and short calculating times. Such tools should be used when timeframes are short, or the budget is restricted.

From a hydrogeological viewpoint, a global model is to be preferred over a spatialized groundwater flow model (see later) when studying highly heterogeneous (e.g karst) aquifers, as such a model can show a hydrosystem as a whole, independent of its internal structure which may be complex and difficult to characterise.

However, as global models cannot show spatial differentiation, they are difficult to use in the following configurations: irregular distribution of pumping sites in a catchment; areas with high recharge; variable aquifer-river exchanges between upstream and downstream, etc. The method will thus be more suitable for single aquifers which are pumped in a spatially regular pattern.

Moreover, from a viewpoint of water-resource management, a global model cannot be used to identify an optimal spatial distribution of abstraction which could take into account the environmental constraints related to the impacts of extraction on surface aquatic environments, such as wetlands and streams.

Finally, if the hydrogeological synthesis shows a spatial heterogeneity of the hydrosystem to be modelled, it may be possible to use a semi-global model. This is based on assembling several interconnected global models representing sub-basins of similar characteristics, and allows the assigning of specific abstraction rates and suitable parameters to each sub-basin. 


\section{Global hydrological models}

("rain-flow" or "rain-level" models)

\section{"Black box" model}

Deconvolution of the signal using transfer functions (response to input stresses)

Not a physically-based model

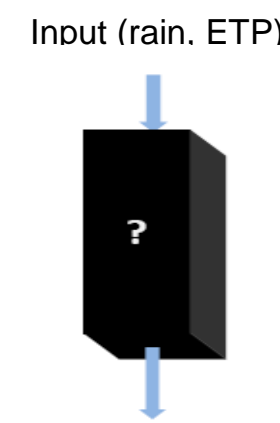

Output (groundwater level, flow-rate)

\section{Reservoir model}

No spatialization, but physical processes (reservoirs, discharge laws).

Not considering governing equations

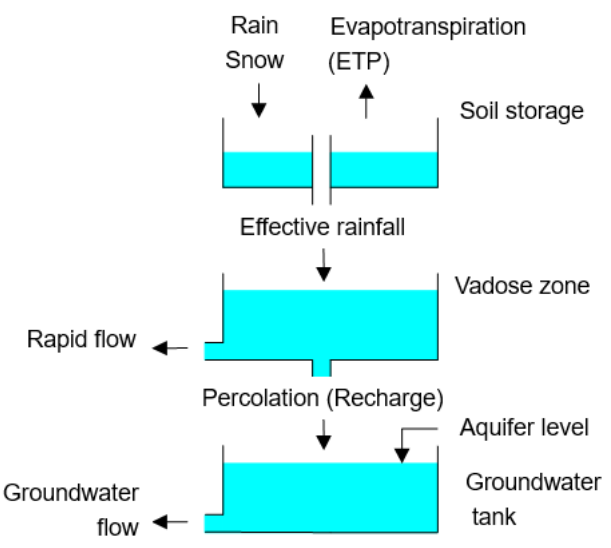

GARDENIA Diagram (BRGM)

Figure 11. 1: The two main global models used in hydrogeology.

Some software packages offer the possibility of considering two underground reservoirs, thus distinguishing between two flow types, e.g. "slow" and "very slow". This option can be interesting for modelling aquifers with double porosity (fissure porosity and matrix porosity in carbonate aquifers, for example).

In all studies using a global model that were examined, the first step consisted in reconstituting the flow-rates and/or the natural water levels, i.e. the values that 
should be theoretically observed in the absence of pumped abstraction. This can be done in several ways (see Box, below).

The software packages used in the studied cases are Tempo (BRGM, 2011) for the "black box" type models, and GARDENIA (Thiéry, 2014) and NAM" for the reservoir models.

\section{Box: Reconstituting natural flow-rates or static water levels}

Strictly speaking, the natural flow-rates (or water levels) should be modelled with a model that was earlier calibrated over a period predating the development of water abstraction. However, lacking historical pre-1980s data, this is rarely possible. Among the work studied, this approach was used on only one occasion for the karstic Mosson aquifer in the Hérault department (BRGM, 2011).

In practice, natural flow rates (or water levels) must be modelled with known abstraction figures. Two options are then possible depending on the software used:

(1) The software considers abstraction from the aquifer, in which case the precipitation/flow-rate calibration can be directly used for the observed flow rates. The natural flow rates are then reproduced by a simulation without abstraction. The abstractable (permissible) volume can then be calculated from the simulation of different abstraction scenarios that result in a minimum flow rate objective for four out of five years.

(2) If the software does not consider abstraction from the aquifer, it will be necessary to improve the existing flow rate dataset with figures from streamflow rates. In that case, the abstractable volume can be calculated from the number of natural flow rates that exceed the minimum flow rate objective, similar to what is done for surface waters. The limitations of this approach, commonly used for unconfined aquifers, are discussed below.

\subsection{Calculating maximum permissible volume by spatialized modelling}

The third methodological approach uses a spatialized, or distributed groundwater flow model (Bear et al., 2010; Anderson et al., 2015). Supported by the equations of subsurface-flow physics, spatialized models are the most complete modelling approach for showing a complex reality, offering the widest range of applications. Examples of such applications can be found in chapters 13 and 18 of this volume.

From a hydrogeological viewpoint, using a distributed model is mandatory where multi-layer aquifer systems are concerned. In such a setting, each aquifer layer can

31 https://www.mikepoweredbydhi.com/products/mike-11 
exchange water through vertical leakage with over- and underlying layers. However, though well-suited to a sedimentary porous environment, distributed models are generally unsuitable for strongly discontinuous environments, such as fissured or karstic aquifers.

Such models also allow showing the hydraulic exchanges between aquifers and streams by mobilizing different approaches. In the context of an unconfined aquifer connected to the surface drainage system, it is recommended to use explicit coupling of underground and surface flow, an increasingly common option in modelling software. In this configuration, the model calculates the flow exchanged between the stream and aquifer in both directions (drainage and infiltration) over time, and for each aquifer cell located below surface water. Software used in the work studied includes Modflow ${ }^{32}$, MARTHE ${ }^{33}$, Feflow $^{34}$ and Talisman ${ }^{35}$.

The construction and calibration of a distributed groundwater flow model requires a large quantity of data:

- Input data: Three-dimensional geological description of the aquifer geometry; structure of the river-drainage network; spatialized description of aquifer hydraulic parameters and stream sampling; rainfall and ETP datasets (or recharge data); and initial water level conditions.

- Calibration data: These correspond to data that must be adjusted or determined during model calibration: hydrogeological properties of modelled formations (permeability, storage and hydraulic boundary conditions) and of streams (thickness and permeability of streambed); parameters involved in hydro-climatic calculations (storage capacity of water in soil, distribution between runoff and infiltration; dephasing caused by the unsaturated zone).

- Observed data (potentiometric levels and gauged flows) that should be reproduced as well as possible during model calibration.

Compared to global modelling, creating a spatialized model takes much longer and requires a far higher budget.

Once calibrated, the model can be used to simulate the effects of various climatic and abstraction scenarios. Determination of the MPVs is done by trial-and-error via the simulation of different abstraction-reduction scenarios. The model is used for

\footnotetext{
32 https://water.usgs.gov/ogw/modflow/
}

33 http://www.brgm.fr/production-scientifique/logiciels-scientifiques/marthe-logiciel-modelisation-ecoulements

34 https://www.mikepoweredbydhi.com/products/feflow

35 https://who.rocq.inria.fr/Martin.Vohralik/Files/Doc_Talisman.pdf 
determining the maximum abstraction for safeguarding the earlier-set environmental objectives.

In addition to such planning simulations, the model can be used for exploratory simulations, showing what happens if the spatial distribution of abstractions is modified. This capability inherent in distributed models can be very useful when preparing for dialogue between stakeholders. The studies carried out in France commonly review the following alternatives:

- Modification of the timing of agricultural groundwater abstraction with a carry-over of part of the summer abstraction into the winter period; for instance in the case when substitution reservoirs are constructed to store this water (see Chapter 18).

- Modification of the spatial distribution of aquifer abstractions: for instance evaluating the impact of increasing the distance of certain wells from a stream (see Chapter 5 on the Beauce region), or of changing the upstream/downstream position in the catchment basin.

- Modification of the distribution of abstraction between different resources: changing from a shallow to a deep aquifer, changing from a stream to an aquifer, etc.

\section{Main difficulties encountered and limits of the studies}

Most of the studies examined for this chapter suffered from the widespread difficulties of obtaining sufficient data to derive reliable estimates of MPVs. The two main data gaps encountered were abstraction volumes and monitoring data, especially for water levels and streamflow.

\subsection{Lack of abstraction data}

With regard to groundwater abstractions, many studies mention the difficulty of accurately quantifying abstractions for agriculture and also those from domestic wells (Rinaudo et al, 2015). Most studies ignored domestic abstraction because of the lack of data. In the case of agricultural use, some studies rely on authorized volumes data rather than actual abstraction data which is largely unknown. Although over $90 \%$ of agricultural wells are equipped meters, they are not systematically monitored by Government agencies (see Chapter 25). In addition, the seasonal distribution of such abstractions is rarely known. However, the studies for determining MPVs require data for at least monthly intervals which must be extrapolated using simplifying assumptions that inevitably create uncertainty.

Similarly, there is little reliable data on the discharge of treated wastewater from water treatment plants into surface or groundwater. Recharge to groundwater due 
to infiltration from gravity irrigation systems is also poorly estimated. All these uncertainties have a direct impact on the accuracy of the estimated MPVs.

\subsection{Insufficient resource monitoring data}

The construction of observation wells for monitoring the water levels in unconfined aquifers is relatively recent in France, occurring during the 1990s and 2000s. Consequently, long hydrogeological time-series data are rare, which obviously hinders the ability to determine MPVs, regardless of whether or not modelling is used in the process. Long-term datasets are indispensable for the development and calibration of models, as they should cover a variety of climatic conditions. This is a particularly critical point when studying minimum river flow conditions, or robust aquifers with large storage that have delayed responses to climatic influences. This prerequisite was not always fulfilled in the studies that were examined.

\subsection{Differences in definition of flow-rate/discharge objectives}

In circumstances where an unconfined aquifer is connected to a stream, the MPV determination often directly depends on the minimum river flow objective defined by the stakeholders before commencement of the technical study. Definition of this minimum flow target thus is essential: the higher it is, the lower the abstraction volume will be for the unconfined aquifer connected with the stream.

In the studies examined, different discharge values are used, mostly based on the Biological Discharge ${ }^{36}$ and Minimum-Flow Discharge ${ }^{37}$ (DOE in French) as found in planning documents such as SDAGE (see Chapters 4 and 5), but also based on analyses of statistically observed discharge rates (QMNA5 ${ }^{38}, \mathrm{VCN} 30^{39}$, etc.). The use of different definitions of target river flow-rates leads to the question of whether or not the results from different catchments can be compared.

Moreover, there is significant uncertainty concerning physical flow-rate measurements in streams, especially for low-water periods when the uncertainty can be $>20 \%$ (Rhône-Mediterranean-Corsica [RMC] Water Agency, 2011). Once more, this uncertainty directly affects the planned flow-rate and the calculated MPV.

${ }^{36}$ Minimum discharge into a stream for safeguarding the life, movements and reproduction of the species living in it. Its estimation is commonly based on using a modelling tool of the habitats of the various fish species.

${ }^{37}$ Value of the minimum discharge at a (nodal) point, above which it is considered that all upstream uses (activities, abstraction, discharge) are in equilibrium with the proper functioning of the aquatic environment. This structural objective is laid down in the SDAGE, SAGE and equivalent documents (www.eaufrance.fr).

${ }^{38}$ Minimum monthly discharge over a 5-year return period.

${ }^{39}$ Average minimum annual discharge calculated over 30 consecutive years. 
Strong uncertainties also affect the evaluation of biological flow-rates that must be respected in streams, and which are imposed by the regulations (AERMC et al., 2013). In the RMC Basin, it is recommended to propose a range of values for such biological flow-rates and their derived MPV values. It should be noted that, even though the recommendation is commonly followed for biological flow-rates, this is rarely the case for the MPVs.

Finally, the stations where biological flow-rates are evaluated are not necessarily the same as the gauging stations on which the modelling is based. In that case, the downstream or upstream biological flow-rate value must be extrapolated, introducing further uncertainty into the hydrological conditions.

\subsection{Limitations associated with the global models}

Three problems were identified concerning the application of global models. Firstly as seen before, a global model must respect certain application conditions because of its globalizing and non-spatialized character. The problem is that some studies applied global models to heterogeneous aquifer systems (multi-layered aquifers), or to aquifers with an irregular spatial distribution of abstraction points. In both cases, the modelling results may be erroneous, but this limitation was not discussed in the studies.

The second problem is related to considering the aquifer abstraction at the scale of a catchment area. Because of its global character, the model cannot distinguish between abstraction near a stream - which will have an immediate impact on discharge - and those far from streams that will affect discharge only after several days, or even weeks or months. Numerous global modelling studies thus consider the abstraction from an unconfined aquifer as direct abstraction from a stream, without attenuation or any lag time. If low water flow occurs in a stream after an irrigation period, this assumption may lead to an optimistic evaluation of the MPV to the extent that it ignores the delayed impact of the wells farther away from the stream.

The third problem encountered in the global modelling work is related to the extrapolation of rainfall/flow rate relationships from one basin to a neighbouring basin. This practice occurs when the data for any basin is insufficient for developing or calibrating a model. In view of the probable differences in abstraction and hydrological functioning between two basins, such extrapolation appears to be particularly uncertain for reconstituting a "natural" flow-rate dataset. However although this option should obviously be used with caution, it could be envisaged if at a minimum, low water flow gauging data is available.

\subsection{Limitations associated with the spatialized models}

Analysis of studies based on the use of spatialized models revealed several specific problems. The first is related to the re-use of existing models that were originally developed for a purpose different from calculating an MPV. Here, the initial 
objectives determined the model type, in particular the extent of the modelled domain. Whether the model is "fit for purpose" for determining an MPV must therefore be verified, and if necessary, the model should be modified and recalibrated.

The second problem is related to the definition of the conceptual flow model that underlies the construction of a distributed model. The studies analysed commonly mention the uncertainties related to the assumptions concerning the geometry of the different aquifer layers to be modelled, the hydraulic conditions at the model boundaries or the type of groundwater-surface water interactions. Imposed flow-rates are quite commonly applied to the model limits without validation being possible. The uncertainty related to such flow can be quite high. Even though such methods may be able to reproduce the potentiometric values of the aquifer, they are not without risk when running the model.

The third problem concerns the often imperfect understanding of the spatial distribution of hydraulic parameters. The adjustment of calibration parameters is effectively equivocal: several combinations of parameters may apparently satisfy the re-transcription of aquifer levels and streamflow. Where aquifers are connected to streams, it is important to test the sensitivity of the results to variations in hydraulic parameters such as streambed permeability (due to clogging) or the aquifer characteristics in a valley bottom (permeability and storage). Such sensitivity analyses are almost never carried out, even though they allow testing the representativeness of the model and understanding the uncertainties associated with the calculated MPVs.

\section{From technical evaluation to decision making: the example of the Adour Garonne Basin}

For about half of the studies that were examined, the calculated MPVs turned out to be lower than the volumes actually abstracted (Table 11.1).

When the imposed reduction in extraction is large, the users may challenge the scientifically based MPV, using both technical arguments that show the limitations of the study methodology and economic arguments stressing the impact of recommended reductions. The technical objections commonly refer to the poor quality of the basic data and thus the uncertainties associated to the results.

In same cases, the resulting negotiations produced a higher MPV figure than that initially calculated. The objective here is to illustrate this phase of negotiation using the example of the Adour Garonne Basin.

\subsection{Economic consequences of reducing the MPV}

In the Adour-Garonne Basin, a strict application of the initially calculated MPVs would have required an average $10 \%$ reduction in the authorized volume at basin scale. Reductions could be as much as $50 \%$ in specific aquifers and negligible in 
others (Hébert et al., 2012). After a very strong backlash against the MPVs, the Adour Garonne Water Agency commissioned a study to quantify the economic impact of MPVs on the agricultural sector (Hébert et al., 2012). This study covered six sub-basins which were considered representative of the diversity of the agricultural economy in the Basin. All six required reductions in abstraction from $28 \%$ to $90 \%$ compared to the existing authorizations for agricultural use (Table 11. 1).

The study was based on a micro-economic modelling of farms, carried out with the stakeholders who systematically validated the choices made for the economic modelling. The results showed that a reduction of MPVs would lead to a 9 to $34 \%$ loss in the economic value of agricultural production ${ }^{40}$ for farms for the various subbasins. The most strongly affected farms would be grain and cattle farmers, whose land commonly is characterized by soils with low soil moisture reserves. Under such conditions, the viability of some farms might even be jeopardized. These results assumed average climatic conditions and average agricultural prices and also showed that, if the water-resource allocation was optimized via a re-allocation of available water volumes to crops with a higher added value, this economic impact would be almost nil. Such re-allocation could take place by proposing compensation, or by establishing a mechanism inspired by a water "market", even though this type of mechanism at present is theoretically impossible in France (see Chapter 3).

Table 11. 1: Examples of study results on determining MPVs (Arnaud, 2016).

\begin{tabular}{|c|c|c|}
\hline $\begin{array}{l}\text { Water } \\
\text { Agency } \\
\text { district }\end{array}$ & $\begin{array}{c}\text { River } \\
\text { catchment }\end{array}$ & $\begin{array}{l}\text { Calculated recommendations for reducing abstrac- } \\
\text { tion }\end{array}$ \\
\hline $\begin{array}{l}\text { Adour Ga- } \\
\text { ronne }\end{array}$ & Seudre & $90 \%$ reduction in agricultural abstraction \\
\hline $\begin{array}{l}\text { Artois Picar- } \\
\text { die }\end{array}$ & $\begin{array}{r}\text { Somme } \\
\text { catchment }\end{array}$ & $20 \%$ reduction in abstraction (reference year 2005) \\
\hline \multirow{3}{*}{$\begin{array}{l}\text { Loire Bre- } \\
\text { tagne }\end{array}$} & $\begin{array}{l}\text { South Ven- } \\
\text { dée }\end{array}$ & Reduction of summer abstraction between 20 and $50 \%$ \\
\hline & $\begin{array}{r}\text { Around the } \\
\text { Poitevin marsh }\end{array}$ & $\begin{array}{l}50 \% \text { reduction in agricultural abstraction: } 70-80 \% \text { in } \\
\text { spring and } 30-50 \% \text { in summer }\end{array}$ \\
\hline & $\begin{array}{r}\text { upstream } \\
\text { Cher SAGE }\end{array}$ & $\begin{array}{l}6 \% \text { reductions in agricultural abstraction compared to } \\
\text { the maximum } 1996-2008 \text { annual abstraction for one sub- } \\
\text { basin and } 32 \% \text { for another }\end{array}$ \\
\hline
\end{tabular}

40 The indicator used in the study was the gross operating surplus (GOS). This allows estimating the profitability of the farming system by neutralizing the effects related to differences in patrimony or investment strategy between the farmers. 


\begin{tabular}{|c|c|c|}
\hline \multirow{9}{*}{$\begin{array}{l}\text { Rhône } \\
\text { Méditerranée } \\
\text { Corse } \\
\text { (RMC) }\end{array}$} & $\begin{array}{l}\text { East Lyons } \\
\text { region }\end{array}$ & $\begin{array}{c}\text { Reduction of } 2.2 \mathrm{Mm}^{3} / \mathrm{yr} \text { after discussions on Meyzieu } \\
\text { management area }\end{array}$ \\
\hline & $\begin{array}{l}\text { Lower Ain } \\
\text { valley }\end{array}$ & $\begin{array}{c}\text { Period 2003-2007: reduction of summer abstraction } \\
\text { (June to August) of between 30\% (2004/2005) and 50\% } \\
(2003)\end{array}$ \\
\hline & $\begin{array}{l}\text { Alluvial aq- } \\
\text { uifer of the Ga- } \\
\text { ron }\end{array}$ & $\begin{array}{l}\text { Period 2002-2009: reduction of abstraction between } 6 \\
\text { and } 43 \% \text { for the prudential scenario }\end{array}$ \\
\hline & Drôme hills & Overall reduction between 20 and $45 \%$ \\
\hline & Galaure & Overall reduction of $40 \%$ \\
\hline & $\begin{array}{l}\text { Roussillon } \\
\text { toll }\end{array}$ & $\begin{array}{c}\text { Reduction between } 30 \text { and } 87 \% \text { in terms of connecting } \\
\text { habitat to aquifer }\end{array}$ \\
\hline & $\begin{array}{l}\text { Véore-Bar- } \\
\text { berolle }\end{array}$ & $\begin{array}{c}40 \% \text { reduction of present abstraction during low-water } \\
\text { periods }\end{array}$ \\
\hline & Lez Basin & $\begin{array}{l}\text { July: reduction of } 17 \% \text { on the Lez and } 40 \% \text { on the Hé- } \\
\text { rin; August and October: free of actual abstraction; Sep- } \\
\text { tember: } 40 \% \text { reduction on the Lez and } 30 \% \text { on the Hérin }\end{array}$ \\
\hline & Eygues Basin & $\begin{array}{l}40 \% \text { reduction in abstraction on the entire basin from } \\
\text { July to September }\end{array}$ \\
\hline $\begin{array}{l}\text { Seine- } \\
\text { Normandy }\end{array}$ & Caen plain & $\begin{array}{l}\text { Reduction of } 2010 \text { abstraction between } 8 \text { and } 82 \% \\
\text { in different management units }\end{array}$ \\
\hline
\end{tabular}

\subsection{Opposition from the farming profession and first political con- cessions by the State}

Since 2008, the farming profession has been strongly opposed to the principle of calculating MPVs based on hydro-meteorological data corresponding to a dry year occurring every five years. This theoretically ensures that in four years out of five, the environmental objectives will be met and the volume allocated to farmers will be available without constraints. However, it also implies that any surplus of water available during these four years will be granted to the environment, which for farmers, represents an unacceptable loss of income.

In order to show their opposition, the farmers' union representatives decided to boycott the consultation meetings from June 2010 (CGEDD and CGAAER, 2015).

Following this first protest to the reform of MPVs, the Ministry for Ecology softened its position (Circular of 3 August 2010). Without calling into question the definition of the MPVs, the Circular planned for financial aid to farmers to assist them to minimise the impact of reducing the MPVs. Such measures are applicable in basins where the difference between present water use and the MPV is over $30 \%$. The first measure proposed prolonging the delay in applying the reduction in ab- 
straction by two years to the end of 2017. The second measure proposed the reduction should take place in a progressive manner up to 2017. The third concession by the State was to accept the principle of a yearly revision of the MPV, considering the volume effectively available at the start of each year, and the actual climatic and hydrologic conditions, in order to avoid an over-restrictive limit in times of abundant resources. In addition, the State proposed more substantial financial assistance through the Water Agencies for the creation of private storage reservoirs (subsidies of up to $70 \%$ compared to the initial $50 \%$ ), which enable the storage of available winter precipitation to compensate for the reduction in authorized abstraction in summer. Finally, the State showed further flexibility by attributing an additional volume of up to $20 \%$ of the scientifically calculated MPV to take into account the uncertainties associated with evaluating the MPVs.

\subsection{The conflict reached the Presidency}

The concessions made by the State in its Circular of 2010 were still considered to be insufficient by the agricultural profession, which then elevated the debate to the national level in November 2010. This resulted in additional adaptive measures, now arbitrated by the French presidency, for implementation in the Basin. Two memoranda of understanding were signed between the State and regional Chambers of Agriculture, the first in June 2011 for the Poitou-Charentes region and a second in November 2011 for the Midi-Pyrénées and Aquitaine regions.

The two memoranda have different content and conditions of application, but both contain the main concessions that were previously negotiated. The application of the MPVs was delayed by a further four years to 2021, instead of 2015 initially. The State finally authorized additional abstraction during spring, depending on the state of the water resource.

Furthermore through these memoranda, the State committed to improving the rigour of the MPV studies (by verifying the relevance of the minimum river flow rates targets), as well as implementing compensatory measures (in particular financial assistance). For their part, the Chambers of Agriculture committed to ensuring the sharing of the available abstractable volumes between agricultural users, as part of the creation of Water Users' Associations (Organisme Unique de Gestion Collective) (see Chapter 3).

Following several years of negotiation, the MPVs for irrigation were notified by the regional Prefects, distinguishing the initial MPVs (derived from scientific studies), the refined initial MPVs (from local consultations before 2011), and the final MPVs which integrate the corrections and flexibility allowed by the memoranda of understanding. Table 11. 2 provides a quantitative illustration of the negotiation process carried out for the Seudre catchment. Here, a $34 \%$ increase was granted compared to the initially planned MPV for agricultural use. To help reduce the abstraction to the MPV, this catchment was the subject of a territorial development project (see Chapter 24). 
Table 11. 2: Maximum permissible volumes notified for the Seudre catchment (Charente-Maritime department)

$\begin{array}{ccccc}\text { Catchment unit } & \begin{array}{c}\text { Authorized } \\ \text { volume }(\mathrm{Mm3})\end{array} & \begin{array}{c}\text { Notified } \\ \text { MPV 2009 } \\ (\mathrm{Mm3})\end{array} & \begin{array}{c}\text { Refined MPV } \\ (\mathrm{Mm} 3)\end{array} & \begin{array}{c}\text { Final MPV } \\ (\mathrm{Mm} 3)\end{array} \\ \begin{array}{c}\text { Upstream Seudre } \\ \text { Middle Seudre }\end{array} & 2.6 & 0 & 1.74 & 1.74 \\ \begin{array}{c}\text { Downstream } \\ \text { Seudre }\end{array} & 6.5 & 0 & 0.5 & 0.6 \\ \quad \text { Total } & 2.5 & 2.2 & 0.5 & 0.6 \\ & 11.6 & 2.2 & 2.74 & 2.94\end{array}$

The negotiation phase is however, not yet complete at the time of writing for the Adour-Garonne Basin, as the November 2011 memorandum of understanding for the Midi-Pyrénées and Aquitaine regions was appealed in the administrative court by environmental protection associations. The judgement was to be rendered in 2018.

\section{Conclusion}

In France, quantitative groundwater management policy is mainly driven by environmental objectives. Groundwater abstraction limits must be set to ensure that water use will not lead to any deterioration of aquifers, groundwater dependent streams and rivers and other aquatic ecosystems. This policy requires the calculation of an abstraction limit, expressed as a volume that if respected, guarantees a good state of aquatic environments for four years out of five. The calculation of this volume requires an in-depth understanding of the hydrogeology of the aquifers being exploited.

For unconfined aquifers, the experience gained from over 30 studies shows that the estimation of MPVs is complicated by numerous uncertainties. The first prerequisite is a good knowledge of the dynamics of the hydrosystems and abstraction volumes, but unfortunately this is rarely achieved. Moreover, both the calculation methods and modelling tools that aim to conceptualize these complex systems have limitations due to the simplifying assumptions required for their application.

In many cases, the calculated maximum permissible volumes were much lower than the previously authorized volumes. Therefore, many of the results were contested by affected users. Such disputes concerned not only the economic consequences of reduced abstraction, but also the scientific basis of the studies in view of the known uncertainties and limitations. 
A negotiation phase at both national and local levels was thus started between stakeholders, experts and government services. Several compromise measures were agreed upon by the State for catchments with large over-allocations, including authorizing an increase in the initially planned abstractable volume. The negotiation process to resolve local disputes is still underway in some areas.

\section{References}

Agence de l'Eau RMC, DIRENs of the RMC Basin, ONEMA (2009) - Études de détermination des volumes maximum prélevables. "Standard" Terms of Reference.

Agence de l'Eau RMC (2011) - Bureau du comité de bassin Rhône Méditerranée. Séance du 10 juin 2011. Point IV : méthodes et études des volumes prélevables.

Agence de l'Eau RMC, IRSTEA, ONEMA (2013) - Note du secrétariat technique du SDAGE. Mieux gérer les prélèvements d'eau. L'évaluation préalable des débits biologiques dans les cours d'eau.

Anderson M.P., Woessner W., Hunt R. (2015) - Applied Groundwater Modeling, $2^{\text {nd }}$ Edition. Academic Press-Elsevier.

Arnaud L. (2016) - Estimation des volumes prélevables dans les aquifères à nappe libre : retour d'expériences sur les méthodes utilisées, identification des problems rencontrés, recommandations. Rapport final, BRGM/RP-64615-FR. 107 p., 42 fig., 1 app.

Bear J., Cheng A.H.D. (2010) - Modeling Groundwater Flow and Contaminant Transport. Springer.

BRGM (2011) - Caractérisation du comportement d'un indicateur piézométrique et définition des volumes prélevables sur les compartiments carbonatés Nord et Sud de l'entité MOSSON de la masse d'eau FR_DO_124. Report BRGM/RP-59658FR.

BRGM (2013) - Connaissances des ressources réellement disponibles sur l'ensemble des bassins versants crayeux de Champagne-Ardenne. Report BRGM/RP61371-FR.

Calligée Consultants (2008) Expertise et objectifs du projet de SDAGE de la ressource en eau sur la bordure Nord du Marais Poitevin vendéen, Bassin du Lay, de la Vendée et des Autizes, et propositions de principes de gestion. Phase 3 : étude d'un cadre de gestion des nappes du Sud-Vendée compatible avec les enjeux écologiques et économiques. Report N08-85138C.

CGEDD, CGAAER (2015) - Evaluation de la mise en œuvre des protocoles Etatprofession agricole conclus en 2011 dans le bassin Adour-Garonne pour la gestion quantitative de l'eau. 
Grontmij, Rivages Environnement (2014) - Identification et préservation des ressources majeures en eau souterraine pour l'AEP. Lot $n^{\circ} 4$ : Etude des alluvions du Gapeau, et des alluvions et formations du Muschelkalk de la plaine de l'Eygoutier. Rapport de phase 2. Etape 3 -Complément à l'étude des volumes maximums prélevables des alluvions du Gapeau. Press.

Healy R.W. (2010) Estimating Groundwater Recharge. Cambridge University

Hébert N., Grandmougin B., Loubier S., Graveline N., Marsac S., Amen J.F., Brunel L. (2012) - Réforme des autorisations de prélèvement dans le bassin AdourGaronne : impacts sur l'économie agricole. Agronomie Environnement et Sociétés, Vol. 2, $\mathrm{n}^{\circ} 2$.

Ministry for Ecology, Energy, Sustainable Development and Territorial Development (2008) - Circular (in French) of 30 June 2008 on the reduction of quantitative disequilibria during water sampling and collective management of irrigation sampling.

Ministry for Ecology, Energy, Sustainable Development and the Sea (2010) Circular (in French) of 3 August 2010 on the reduction of quantitative disequilibria during water sampling and collective management of irrigation sampling in basins where the difference between abstracted volume during a five-yearly dry year and the volume that can be abstracted is over $30 \%$.

Préfet de la Région Midi-Pyrénées (2011) - Notification des volumes prélevables sur la région Poitou-Charentes.

Rinaudo J.D., Montginoul M. Desprats J.F. (2015) The Development of Private Bore-Wells as Independent Water Supplies: Challenges for Water Utilities in France and Australia. In: Grafton et al. Understanding and Managing Urban Water in Transition. Springer, 155-174.

Sood A., Smakhtin V. (2015) Global hydrological models: a review, Hydrological Sciences Journal, 60:4, 549-565, DOI: 10.1080/02626667.2014.950580

Thiéry D. (2014) - GARDÉNIA software, version 8.2. User Guide. BRGM/RP62797-FR report, 126 p., 65 fig., 2 app. 